\title{
THE RELATIONSHIP BETWEEN SELF DISCLOSURE WITH RESILIENCE IN TEENAGE GIRLS AT X ORPHANAGE, PADANG CITY
}

\author{
Rahmawati \\ Natalyarahmawaty@yahoo.com \\ Fakultas Psikologi \\ Universitas Gunadarma \\ Jalan Margonda Raya No.100, Depok 16424
}

\begin{abstract}
Abstrack
The purpose of this research is to observe the relationship between self disclosure with resilience in teenage girls at $\mathrm{X}$ orphanage in Padang City. The dependent variable in this research is resilience, and the independent variable is self disclosure. The measurement tool being used in this research is the dimension-based resilience scale that was coined by Grotberg and the self dimension-based disclosure scale that was put forward by Devito. The sampling technique in this research is the purposive sampling. Samples in this research are 40 teenage girls.

The validity and reliability tests in this research uses the Alpha Cronbach Technique. The result of validity coefficient in the self disclosure scale moves between rix $=0,196$ up to rix $=0,723$, and the reliability coefficient is at $\alpha=0,925$, while the resilience scale moves from rix $=0,199$ up to rix $=0,725$ with reliability coefficient of $\alpha=0,964$, which then resulted in rxy=0,416 with a $\mathrm{p}=0,004$ significance. Based on the result of the data analysis, it can be concluded that there is a significant relationship between self disclosure with resilience. The effective contribution of the resulting analysis between self disclosure and resilience is $17 \%$.
\end{abstract}

Key words : Self disclosure, Resilience, Teenage Girls, Orphanage

\section{Introduction}

Nowadays, we often find abandoned children without anyone willing to take any responsibility for them. Many children has to face loss or forced to be separated by their parents because of the parents' inability to provide basic child care. We found many reasons while in observing these particular cases. The phenomenon is that there are not many foster parents that can take care of these children, or a lack in means to provide facility, in terms of material and or immaterial, in order to support the children's development. Thus, it demands the role of the government to provide social facility in the form of orphanage. These children are placed in the orphanage as an alternative nurturing home. Separation and traumatic condition significantly impacted on the physical, behavioral, emotional, and cognitive aspects of a child, that can influence the childs' development to their next stage, adolescent stage.

Santrock (2003) stated that transition in teenagers can be observed from their behavior such as the trouble they caused, their lack of respectfulness, tendency to focus more on themselves, becoming more aggressive, and taking more risks. Santrock continued that some teenagers are able to overcome this transition period, but those who could not, tend to face a regress in their physical, psychological, and social condition. In psychological study, the psychological ability of an individual in facing a disadvantegous condition is called as resilience (Masten in Ayu, 2017). In human development study, resilience has a broader and varied meaning, consisting of recovery from traumatic experience, overcoming failure in life, and stress management in order to be able to fully function in everyday life.

Endang (Rahmi, 2018) stated that one way to ease problems and burdens is by applying self disclosure. Opening up oneself or self disclosure is one of the key factor that is needed in interpersonal relationship, which able oneself to express their respond, feeling, and wishes, that resulted in openness. An open relationship will resulted in a positive reciprocate relationship that gives out the feeling of safe, acceptance, and a deep understanding of oneself, as well as resolving life's problems (Ningsih, in Ramli, 2018).

Teenagers without the ability to apply self disclosure while facing their problem, tends to find it hard to find a solution. This differ with teenager that are able, as they can share and find answers for their problems, which in turn will avoid them from physical and psychological effects (Ningsih in Ramli, 2018).

Researcher has done an observation and preliminary interview on three troubled teenage girls at $\mathrm{X}$ Orphanage in Padang City, on the 25th of November 2020. Few problems that was gathered were some changes in their teenage life that needed adaptation, such as adapting to a new surrounding, new friends, new rules in a new environment. Other changes are a new style of learning process, where as teenager are demanded to be independent, able to manage limited fund, time management and improving self discipline. These teenagers stated that they have difficulty in adjusting to those changes and having a lack of confidence towards themselves. If they are facing problems, they tend to feel despair, stress, and being in silence, as well as feeling 
sad whenever they remember their family and parents. The rules in the orphanage is also quite strict, which the management does not give the chance for them to make their own decision, such as for example, choosing the school that they want to apply to.

Moreover, these teenage girls also feels uncomfortable with the behavior of some of their friends that resulted in fights. Teenage girls in an orphanage tend to be insensitive to other people's feelings. However, not all of them are like that, some are able to face and overcome their problems regarding adaptation. Other problem in the orphanage is that some of these teenage girls felt that anything about them is a secret that can not be shared, which makes it hard for others to be able to fully understand due to the undetailed information that they only willing to share. By being closed off, these teenager girls are unable to share or ask their friends or their caretaker, and unable to convey the problems that they are facing and how they feel.

\section{Literature Review}

To the best of one's knowledge, research regarding resilience has also been conducted by Cantika Yeniar Pasudewi (2019), Malang State University student, with the title "Resilience on Correctional Centre Teenagers in terms of Coping Stress". The differences are on the variables and samples that are being used, time of research, as well as the place of research. In that research, the independent variable is coping stress and the dependent variable is resilience. The samples are teenagers from correctional centre. The result of that research is that there are no differences in resiliency between teenagers with emotional-focused coping mechanism with teenagers with problem-focused coping mechanism.

Research concerning self disclosure have also been conducted by Prima Saripa Rahmi (2019), Putra Indonesia YPTK Padang University student, with the title of "The Relationship between Self Disclosure with Adversity Quotient on Thesis-Composing Student of Psychology Faculty at Putra Indonesia YPTK Padang University". The result of the research showed that there are connection between self disclosure with adversity quotienton those students. The differences with other research are on the variables, samples, time and place of research.

\section{Research Methode}

This research is purely an experiment to observe the correlation between dependent and independent variables that will be analyzed with the Product Moment Correlation Technique, which is one of the main correlation technique that is used to find relation and prove hypothesis between two variables, based on their interval and ratio data and from the same data resource (Sugiyono, 2012).

The subjects of this research are gathered by using purposive sampling technique, where the sampling is done based only on the researcher's consideration that the expected components is already within the chosen samples, which is 40 teenage girls.

The measuring tool in this research is in the form of a scale. Scale in this research has a format respond with 4 alternative answers, which are SS (Sangat Sesuai), S (Sesuai), TS (Tidak Sesuai), dan STS (Sangat Tidak Sesuai). The aspect for self disclosure scale refer to the self disclosure dimension which was put forward by Devito (Lukaningsih, 2018) which are : self disclosure measurement, self disclosure valence, precision and honesty, purpose and meaning, and intimacy. Meanwhile, the resiliency level in this research is measured by using resilience scale which was designed based on the resilience characteristics coined by Grotberg (Handayani, 2019) which are : I have, I am, and I can.

Previously, researcher has done a Try Out of research scale, where the self disclosure scale validity coefficient was set at 0.30 , where we gathered 36 valid and reliable items from 45 statements ( 9 items was deemed invalid), with a range of corrected item total correction between 0.196 to 0.723 . whereas on the resilience scale, the validity coefficient was set at 0.30 , which resulted in 73 valid and reliable items from 79 statements (6 items was considered invalid), with a range of corrected item total correction between 0.199 to 0.725 .

As for the reliability test on self disclosure scale using Alpha Cronbach analysis technique resulted in 0.925 . The result for reliability test on resilience scale using the same analysis technique resulted in a coefficient of 0.964 . This showed that the measuring tools that was used in this research has a high level of reliability.

\section{Result}

\section{Normality Test Results}

Normality test in this research uses the Kolmogorov-Smirnov test in order to determine whether the chosen samples comes from a normally distributed population (Canpil, 2018). Based on the data processing result using SPSS 21.0 Program for Windows, researcher obtained the result as shown on the following table. 
Table 4.1 Scale Normality Test Result Table of Self Disclosure and Resilience

\begin{tabular}{ccccc}
\hline Variable & N & KSZ & P & Range \\
\hline Self Disclosure & 40 & .736 & .651 & Normal \\
Resilience & 40 & .773 & .589 & Normal \\
\hline
\end{tabular}

Based on the above table, the significancy value that we found on the self disclosure scale is $\mathrm{p}=0.651$. That result shows that value $\mathrm{p}>0.05$, which means the range of the self disclosure scale is normally distributed, at the same time, the resilience scale is at $\mathrm{p}=0.589$ for its significancy value, which also showed that it is normally distributed.

\section{Linearity Test Result}

The linearity test uses the Test for Linearity with a 0.05 significance level. Two variables can described as connected linearly if the significancy is less than 0.05. This test was done using SPSS 21.0 Program for Windows, which the results can be seen on the following table.

Table 4.2 Linearity Test Result Table

\begin{tabular}{ccccc}
\hline $\mathbf{N}$ & $\mathbf{D f}$ & Mean square & F & Sig \\
\hline 40 & 25 & 947.969 & 0.928 & 0.024 \\
\hline
\end{tabular}

Based on the table above, we obtained value of $F=0.928$ with a significance level of $p=0.024(p<0.05)$, thus showed that the self disclosure and resilience scale can be categorized as linear.

\section{Hypothesis Test Results}

The research data processing regarding the relatioship between self disclosure and resilience on teenage girls at X Orpahanage in Padang City uses the Pearson Product Moment Statistic Test with the assist of the SPSS 21.0 Program for Windows. The Product Moment correlation test result can be seen from the following table.

Table 4.3 Test Result Tables between Self Disclosure with Resilience

\begin{tabular}{lllll}
\hline $\mathbf{N}$ & $\mathbf{P}$ & Correlation number $(\mathbf{r})$ & R square & Conclusion \\
\hline 40 & 0.004 & 0.416 & 0.173 & Hypothesis accepted \\
\hline
\end{tabular}

Based on the correlation result above, the significance correlation between self disclosure with resilience is at $r=0.416$ with a $p=0.004$ significance value. This shows that the correlation is positive, which translate that if the resilience are good, then the self disclosure of these teenage girls are high. On the other hand, if the resilience are bad, then the self disclosure would be low. This is strengthened by the significance test result which resulted in a $\mathrm{p}=0.004<0.01$ level of significant $(\alpha)$, thus hypothesis is accepted, that there is a signficant relationship between self disclosure with resilience for the teenage girls at $\mathrm{X}$ Orphanage.

\section{Research Variable Description}

The categorization used on self disclosure with resilience on teenagers is divided into three level, which are low, medium, and high. Meanwhile, the statistic calculation in the variables categorization of self disclosure and resilience can be seen on the following tables :

Table 4. 4 Descriptive Statistic Table of Self Disclosure with Resilience

\begin{tabular}{cccccc}
\hline Variable & N & Min & Max & Mean & SD \\
\hline Self Disclosure & 40 & 78 & 133 & 103.00 & 13.961 \\
Resilience & 40 & 138 & 253 & 201.23 & 31.214 \\
\hline
\end{tabular}


Table 4. 5 Category Table of Self disclosure with Resilience Ability

\begin{tabular}{ccccc}
\hline Variable & Score & Total & \% & Category \\
\hline \multirow{3}{*}{ Self Disclosure } & $\mathrm{X}<89$ & 5 & $12.5 \%$ & Low \\
& $89-116$ & 27 & $67.5 \%$ & Medium \\
& $\mathrm{X}>117$ & 8 & $20 \%$ & High \\
& $\mathrm{X}<170$ & 8 & $20 \%$ & Low \\
Resilience & $170-232$ & 27 & $67.5 \%$ & Medium \\
& $\mathrm{X}>233$ & 5 & $12.5 \%$ & High \\
\hline
\end{tabular}

Based on the tables above, it can be described that $12.5 \%$ of the teenage girls at the orphanage has low self disclosure, while $67.5 \%$ of them has medium self disclosure, and $20 \%$ are at a high level. At the same time, $20 \%$ of the teenage girls has low resilience, while $67.5 \%$ of them has medium level resilience, and $12.5 \%$ are at a high level.

\section{Effective Contribution}

The effective contribution from variables of the relationship between self disclosure and resilience can be determined by using Determinant Coefficient Formula. The determinant coefficient degree can be calculated by using the following formula :

\section{Determinant Coefficient}

$\mathrm{KP}=\mathrm{r}^{2} \times 100 \%$

$\mathrm{KP}=0,416^{2} \times 100 \%$

$=0.173056 \times 100 \%$

$=17 \%$

\section{Discussion}

Based on the data processing result, we obtained a result that shows there are significant relationship between self disclosure and resilience of teenage girls at X Orphanage in Padang City, with a correlation coefficient (r) 0.416 with significance degree of $p=0.004$. This shows that the hypothesis can be accepted, with a positive relationship. In other words, the higher the self disclosure or openness of these teenage girls, then the higher their resilience are. Oppositely, the lower the self disclosure then the lower the resilince are for these teenage girls at X Orphanage in Padang City.

We can also analyze from the data that teenage girls who faces difficult condition at the orpahanage, but possess a high self disclosure level, then they also possess a high level of resiliency in facing those difficult condition. The result of Rahmi's research (2018) showed that teenager who are able to perform self disclosure, they tend to find a solution from the problem that they are facing due to the feedback that they received from others. This is in line with what Endang (Novianna, 2017) had proposed that one of the way to relieve problem's pressure is by self revealing or self disclosure. Taylor (2019) also added that one of the reason for self disclosure is to minimize stress. Self disclosure or self openness is simply defined as opening up, which means sharing one's feeling or information regarding with what we said, did or how we felt about an event that was seen, to other people.

Resiliency of the teenage girls at X Orphanage in Padang City mostly are at the medium level of $67.5 \%$ or approximately equals to 27 teenage girls, 5 of them are at a high level (12.5\%), while $20 \%$ or 8 teenage girls are at a low level. As for self disclosure, $67.5 \%$ or 27 girls are at a medium level, while $12.5 \%$ of them are on the low category, completed by 8 girls or $20 \%$ at a high level.

Based on the result of the data processing regarding the effectiveness contribution of self disclosure on resilience, we obtained the effective contribution value (KP) of $17 \%$, while the remaining $83 \%$ was influenced by other factors. Desmita (2009) stated that other factors that can influence resilience are trust, autonomy, initiative, ability to solve problem, and identity. 


\section{Conclussion And Sugesstion}

Based on the analysis result that has been explained above, we can conclude and answer the problem formula of this research, which are :

1. There are connectivity or relatioship between self disclosure with resilience on teenage girls in $X$ Orphanage at Padang Ciy. This shows that the hypothesis is accepted.

2. The effective contribution (KP) from self disclosure variables with resilience is at $17 \%$, while the remaining $83 \%$ was influenced by other factors.

The researcher tries to give some suggestions that can be used as consideration which is expected to be useful, including:

1. Teenage girls are expected to practice the ability to be aware when a problem arises, then analyze the problem and make notes about things to solve problem, and not blame themselves or others for a problem.

2. Teenage girls can sharing with friends at the orphanage about their feelings and thoughts. The existence of care, appreciation, encouragement and advice from his friends. The social support from caretaker also makes it easier for young women to seek help when experiencing problems. Caretaker also live in the same dormitory, so if they have problems or need help, they talk to the caretaker. Thus, teenage girls will more easily adapt to problems and have resilience with their problems even though they live in orphanages.

3. For the orphanage, especially caretaker to provide psychological support to teenage girls such as advice and suggestions, and willing to listen to teenagers' complaints, so that teenagers do not feel burdened by their problems.

\section{References}

Astuti, Putri Novia. (2019). Pengalaman Psikososial Anak Remaja Putri di Panti Sosial Asuhan Anak Putra Utama 3 Tebet. Skripsi: Universitas Islam Negeri Syarif Hidayatullah, 9, 40-51

Ayu, Ambar Lestari. (2017). Hubungan Antara Religiulitas Dengan Resiliensi Pada Ibu Yang Memiliki Anak Retardasi Mental. Skripsi: Universitas Kristen Satya Wacana.

Azwar, Saifuddin. (2020). Penyusunan Skala Psikologi. Yogyakarta: Pustaka Pelajar.

Azwar, Saifuddin. (2020). Metode Penelitian. Yogyakarta: Pustaka Belajar.

Canpil, Nevy Izmi. (2018). Hubungan Antara Berfikir Positif Dengan Kemampuan Pemecahan Masalah Interpersonal Pada Santri di Asrama Putri Pondok Pesantren Madrasah Aliyah Islamiyah Batang Kabung Padang. Skripsi: Universitas Putra Indonesia "YPTK" Padang.

Desmita. (2009). Psikologi Perkembangan.Bandung: PT. Remaja Rosdakarya

Devito, Joseph. A. (1997). Komunikasi Antar-Manusia Kuliah Dasar Edisi Kelima.Penerjemah: Agus Maulana. Jakarta: Profesional Books.

Handayani, Firanti. (2019). Hubungan Antara Kekuatan Karakter Dengan Resiliensi Residen Narkoba di Unit Pelaksana Teknis (UPT) Terapi Dan Rehabilitasi Badan Narkotika Nasional LIDO. Skripsi: Universitas Islam Negeri Syarif Hidayatullah, 7, 11-12

Hurlock, Elizabeth. (2014). Psikologi Perkembangan Suatu Pendekatan Sepanjang rentang Kehidupan.Edisi kelima. Jakarta: Erlangga

Lukaningsih, Zuyina Luk. (2018). Pengembangan Kepribadian. Yogyakarta: Nuha Medika.

Morissan. (2010). Psikologi Komunikasi. Bogor: Ghalia Indonesia.

Pasudewi, Cantika. (2019). Resiliensi Pada remaja Binaan Bapas di Tinjau Dari Coping Stress. Skripsi: Universitas Indonesia, 11, 20-26 
Rahmi, Saripa Prima. (2014). Hubungan Antara Self Disclosure Dengan Adversity Question Pada Mahasiswa Yang Sedang Menyusun Skripsi Fakultas Psikolgi Universitas Putra Indonesia "YPTK" Padang. Skripsi: Universitas Putra Indonesia "YPTK" Padang.

Ramli, Rahmi. (2018). Hubungan Antara Atraksi Interpersonal Dengan Self Disclosure Pada Siswa SMPN 25 Padang. Skripsi: Universitas Putra Indonesia "YPTK" Padang.

Remenia, Ingrid. (2019). Pengaruh Konsep diri Terhadap Penyesuaian Diri Pada remaja Penghuni Panti Asuhan. Skripsi: Universitas Muhammadiyah Malang, 8, 11-12

Santrock, Jhon. W. (2007). Remaja.Jakarta: Erlangga.

Sarwono, Sarlito. (2007). Psikologi Remaja. Jakarta: PT. Raja Grafindo Persada

Sugiyono. (2012). Statistika Untuk Penelitian. Bandung: Alfabeta.

Taylor, Shelley E, dkk. (2019). Psikologi Sosial. Edisi 12. Penerjemah: Tri Wibowo. Jakarta: Kencana.

Widuri, Listiyanti Erlina. (2017). Regulasi Emosi Dan Resiliensi Pada Mahasiswa Tahun Pertama. Jurnal Psikologi: Universitas Ahmad Dahlan. Volume IX, 2-8

Yuniardi, M. S. (2009). Analisis potensi resiliensi korban lumpur panas Lapindo: Tinjauan pada tiap tahap perkembangan. Jurnal Psikologi: Universitas Muhammadiyah Malang, 4, 55-56

Yuniardi, M. Salis \& Djudiyah. (2011). Support Group Therapy Untuk Mengembangkan Potensi Resiliensi Remaja Dari keluarga Single Parent di Kota Malang. Jurnal Psikologi: Universitas Muhammadiyah Malang, 3, 2-4

Zalfa, Khulaimata. (2014). Penerapan Konseling Singkat berfokus Solusi (Solution-Focused Riset Counseling) Untuk Mengembangkan Resiliensi Santri. Thesis: Universitas Pendidikan Indonesia Bandung, 1, 12-19. 